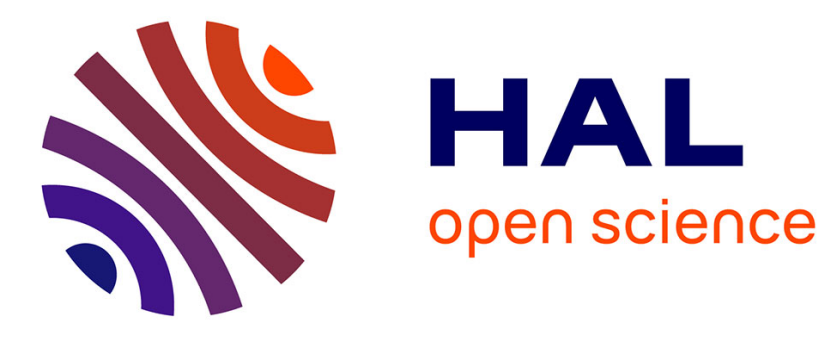

\title{
Performance of the Abbott RealTime High Risk HPV test in women with abnormal smears
}

\author{
Jack Cuzick, Laurence Ambroisine, Louise Cadman, Janet Austin, Linda Ho, \\ George Terry, Stuart Liddle, Roberto Dina, Julie Mccarthy, Hilary Buckley, et \\ al.
}

\section{To cite this version:}

Jack Cuzick, Laurence Ambroisine, Louise Cadman, Janet Austin, Linda Ho, et al.. Performance of the Abbott RealTime High Risk HPV test in women with abnormal smears. Journal of Medical Virology, 2010, 82 (7), pp.1186. 10.1002/jmv.21801 . hal-00552413

\section{HAL Id: hal-00552413 https://hal.science/hal-00552413}

Submitted on 6 Jan 2011

HAL is a multi-disciplinary open access archive for the deposit and dissemination of scientific research documents, whether they are published or not. The documents may come from teaching and research institutions in France or abroad, or from public or private research centers.
L'archive ouverte pluridisciplinaire HAL, est destinée au dépôt et à la diffusion de documents scientifiques de niveau recherche, publiés ou non, émanant des établissements d'enseignement et de recherche français ou étrangers, des laboratoires publics ou privés. 


\section{Journal of Medical Virology}

WILEY

\section{Performance of the Abbott RealTime High Risk HPV test in women with abnormal smears}

\begin{tabular}{|r|l|}
\hline Journal: & Journal of Medical Virology \\
\hline Manuscript ID: & JMV-09-1555.R1 \\
\hline Diley - Manuscript type: & Research Article \\
\hline Author: & 11-Feb-2010 \\
\hline Complete List of Authors: & $\begin{array}{l}\text { Cuzick, Jack; Queen Mary University of London, CRUK Centre for } \\
\text { Epidemiology, Mathematics and Statistics } \\
\text { Ambroisine, Laurence; Queen Mary University of London, CRUK } \\
\text { Centre for Epidemiology, Mathematics and Statistics } \\
\text { Cadman, Louise; Queen Mary University of London, CRUK Centre } \\
\text { for Epidemiology, Mathematics and Statistics } \\
\text { Austin, Janet; Queen Mary University of London, CRUK Centre for } \\
\text { Epidemiology, Mathematics and Statistics } \\
\text { Ho, Linda; Queen Mary University of London, CRUK Centre for } \\
\text { Epidemiology, Mathematics and Statistics } \\
\text { Terry, George; Queen Mary University of London, CRUK Centre for } \\
\text { Epidemiology, Mathematics and Statistics } \\
\text { Liddle, Stuart; The Doctors Laboratory } \\
\text { Dina, Roberto; Hammersmith and Queen Charlotte's \& Chelsea } \\
\text { Hospitals, Cytopathology Department } \\
\text { McCarthy, Julie; St. Mary's Hospital, Cytopathology Department } \\
\text { Buckley, Hilary; St Mary's Hospital, Department of Pathology } \\
\text { Bergeron, Christine; Laboratoire Pasteur-Cerba } \\
\text { Soutter, William; Hammersmith and Queen Charlotte's \& Chelsea } \\
\text { Hospitals, Department of Gynaecology } \\
\text { Lyons, Deirdre; St Mary's Hospital } \\
\text { Szarewski, Anne; Queen Mary University of London, CRUK Centre } \\
\text { for Epidemiology, Mathematics and Statistics }\end{array}$ \\
\hline Keywords: & $\begin{array}{l}\text { HPV testing, Cervical Screening, Abbott RealTime High Risk HPV } \\
\text { Test, Sensitivity, Specificity }\end{array}$ \\
\hline \hline
\end{tabular}

\section{s ScholarONE \\ Manuscript Central}




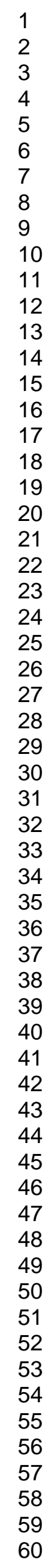

John Wiley \& Sons 
Abbott RealTime High Risk HPV

\section{Performance of the Abbott RealTime High Risk HPV test in women with abnormal smears}

Jack Cuzick $^{1}$, Laurence Ambroisine ${ }^{1}$, Louise Cadman ${ }^{1}$, Janet Austin ${ }^{1}$, Linda Ho ${ }^{1}$, George Terry $^{1}$, Stuart Liddle ${ }^{2}$, Roberto Dina ${ }^{3}$, Julie McCarthy ${ }^{4}$, Hilary Buckley ${ }^{5}$, Christine Bergeron ${ }^{6}$, WP Soutter ${ }^{7}$, Deirdre Lyons ${ }^{8}$, Anne Szarewski $^{1}$

1. Cancer Research UK Centre for Epidemiology, Mathematics and Statistics, Queen Mary University of London, Barts \& The London School of Medicine and Dentistry, Wolfson Institute of Preventive Medicine, Charterhouse Square, London, EC1M 6BQ, UK

2. The Doctors Laboratory, 60 Whitfield Street, London, W1T 4EU, UK

3. Cytopathology Department, Hammersmith and Queen Charlotte's \& Chelsea Hospitals, Du Cane Rd, London, W12 0HS, UK

4. Cytopathology Department, St Mary's Hospital, Praed Street, London, W2 1PG, UK

5. Department of Pathology, St Mary’s Hospital, Whitworth Park, Manchester, M13 0JH, UK

6. Laboratoire Pasteur-Cerba 95066 Cergy Pontoise Cedex 9, France

7. Department of Gynaecology, Hammersmith and Queen Charlotte's \& Chelsea Hospitals, Du Cane Rd, London, W12 0HS, UK

8. St Mary’s Hospital, Praed Street, London, W2 1PG, UK 
Corresponding Author:

Professor Jack Cuzick

John Snow Professor of Epidemiology

Cancer Research UK Centre for Epidemiology, Mathematics and Statistics

Queen Mary University of London

Barts \& The London School of Medicine and Dentistry

Wolfson Institute of Preventive Medicine

Charterhouse Square

London EC1M 6BQ

United Kingdom

Email: j.cuzick@qmul.ac.uk 
Abbott RealTime High Risk HPV

\begin{abstract}
HPV DNA testing is known to be much more sensitive than cytology, but less specific. A range of HPV and related tests in 858 women referred for colposcopy because of an abnormal smear were evaluated to compare the performances of these tests. This paper compared the Abbott test to other tests which had been previously evaluated. This test was a real true test for 14 high risk HPV types. The Abbott test was found to be highly sensitive for cervical intraepithelial neoplasia grade 3 or worse $(\mathrm{CIN} 3+)(98.9 \%)$ with a specificity of $31.5 \%$. These numbers were comparable with the Qiagen HC2 test, the Roche Linear Array and Amplicor tests, and the Gen-Probe APTIMA test. Differences between these tests appeared to be related mostly to the choice of cutoff level. An added feature of the Abbott test was the provision of type specific results for HPV 16 and 18.
\end{abstract}

\author{
Key Words \\ HPV testing \\ Cervical Screening \\ Abbott RealTime High Risk HPV Test \\ Sensitivity \\ Specificity
}




\section{Introduction}

High risk (HR) HPV is a necessary factor for the development of cervical cancer (Walboomers et al. [1999]) but the presence of HR HPV DNA does not lead invariably to disease. Recently it was found that the detection of HR HPV provides high sensitivity but has lower specificity than cytology for the identification of high grade cervical lesions in a screening population in the UK (Cuzick et al. [2003]) and this finding has been replicated in several other studies (Cuzick et al. [2006], Almonte et al. [2007], Bulkmans et al. [2007], Mayrand et al. [2007], Naucler et al [2007], Kotaniemi-Talonen et al. [2008], Ronco et al. [2008]). In addition, several studies have shown that HR HPV DNA positive women are significantly more likely to develop high grade cervical intraepithelial neoplasia (CIN) than women with a negative HPV DNA test (Bulkmans et al. [2005], Khan et al. [2005]) and that a negative HPV test offers a longer period of low risk (protection) of developing high grade cervical intraepithelial neoplasia (CIN) than a negative cytology result (Cuzick et al. [2008], Dillner et al. [2008]). If testing for HR HPV DNA is to be used as a primary cervical screening test, refinements or additional tests are highly desirable to improve specificity while retaining its very high sensitivity.

The introduction of a liquid-based medium for collection of cytological specimens has allowed other molecular techniques to be evaluated more easily as the sole initial test, as an adjunctive test with cytology or as a triage test in women with minimal cytologic abnormalities. In a previous report we compared directly the sensitivity and specificity of a range of tests from the same sample for the detection of high grade cervical intraepithelial 
neoplasia (CIN) in a population referred to colposcopy because of abnormal cytology (Szarewski et al. [2008]). In this report the Abbott RealTime which detects High Risk (HR) HPV test is evaluated, which detects fourteen high risk HPV types (16, 18, 31, 33, 35, 39, 45, $51,52,56,58,59,66$, and 68 ) with type specific detection for types 16,18 , and detection of the other twelve types as a group. In addition, a separate (fourth) channel is used to detect beta-globin as an internal control for sample adequacy. Although designed as a qualitative test utilizing real-time PCR technology, the test also provides cycle number that is generally indicative of the amount of viral DNA present in the sample. Thus high risk HPV detection and HPV16, HPV18 typing results are provided for each sample in addition to the check for sample cellularity. All the tests were compared against the gold standard of histopathology. 
Abbott RealTime High Risk HPV

\section{Methods}

The study population comprised of women who had been referred to the colposcopy clinics at the Hammersmith and St. Mary's Hospitals in London between August 2005 and January 2007. While not a screening population, the advantage was a broad range of outcomes and a high disease rate, which would enable accurate evaluation of sensitivity and specificity in a relatively small number of samples. Women were eligible if they had been referred as a result of one or more abnormal cervical smears, were not pregnant, had not been treated previously for cervical intraepithelial neoplasia (CIN), nor had a hysterectomy. All women received a patient information sheet explaining the study and provided written consent. Approvals were obtained from the relevant Local Research Ethics Committees.

Prior to colposcopy, a cervical sample was obtained using a Cervex broom and placed in PreservCyt ${ }^{\circledR}$ transport medium. Colposcopy was then performed in the usual manner. The liquid based cytology (LBC) samples were transported to The Doctors' Laboratory (TDL), where an aliquot was first removed for cytology, processed using the ThinPrep system and returned to the relevant cytopathology departments for reporting. The following tests were performed on remaining aliquots of the material, Hybrid Capture II (Qiagen, Hilden, Germany), Pretect HPV Proofer (Norchip, Klokkarstug, Norway), Amplicor and Linear Array (Roche, Basel, Switzerland), APTIMA (Gen-Probe, San Diego, CA, USA), ClinicalArrays (Genomica, Madrid, Spain), CINtec p16 ${ }^{\mathrm{INK} 4 \mathrm{a}}$ (mtm Laboratories, Heidelberg, Germany), and our in-house qPCR test. The characteristics of these tests are summarised in Table 1. Aliquots remained for 858 women, which were used to perform the Abbott test in our lab. 
Abbott RealTime High Risk HPV

\begin{abstract}
Abbott RealTime HR HPV is a real-time PCR assay performed on the automated $m 2000$ system that detects fourteen high-risk HPV types, 16, 18, 31, 33, 35, 39, 45, 51, 52, 56, 58, 59, 66, and 68 and simultaneously types HPV 16 and HPV 18. The test also features an internal control for specimen cellularity by detecting an endogenous human beta-globin sequence. Through the distinct probe labels and multi-colour detection system, signals for HPV16, HPV18, non-16/18 HR types, and internal control are simultaneously detected and distinguished in a single reaction. $0.4 \mathrm{~mL}$ aliquot of the PreservCyt sample is processed and DNA is purified using magnetic microparticle technology. This test amplifies a conserved L1 region of approximately 150 base pairs with a modified GP5+/6+ primer mix. Threshold cycle number of 32 as determined from the amplification curve is the assay cutoff recommended by the manufacturer. One positive and one negative control are included in each run to assess run validity.
\end{abstract}

Methods for the other assays have been described previously (Szarewski et al. [2008]). The molecular testing laboratories were blinded to the cytology and histopathology results.

Histopathology was first reported locally and then reviewed centrally by either Dr Hilary Buckley ( $92 \%$ of samples) or Dr. Christine Bergeron ( $8 \%$ of samples), who were blinded to all study test results but did have access to the concurrent cytology. All results are presented based on the reviewed histopathology and the highest grade of abnormality seen in the biopsy or treatment specimen was used. 
Abbott RealTime High Risk HPV

\section{Statistical methods}

Data entry and statistical analyses were carried out at the CRUK Centre for Epidemiology, Mathematics and Statistics. All statistical analyses were carried out using Stata 9.2 (StataCorp, USA).

It was determined that a minimum of 500 patients would be needed to have $80 \%$ power to detect a change in sensitivity from $80 \%$ to $90 \%$ assuming a $25 \%$ prevalence of CIN $2+$ and a discordance rate of $3.6 \%(18 / 500)$. This number of subjects would give at least $90 \%$ power to detect improvements in specificity from $50 \%$ (common in triage) to $75 \%$.

The gold standard was histologically confirmed high grade cervical intraepithelial neoplasia grade 2 or worse (CIN 2+), but calculations were also made for histologically confirmed cervical intraepithelial neoplasia grade 3 or worse (CIN3+). The sensitivity, specificity and positive predictive value (PPV) of each test were computed and $95 \%$ confidence intervals were obtained using exact binomial methods when necessary. Additional calculations of sensitivity, specificity and PPV were carried out for different age groups. 
Abbott RealTime High Risk HPV

\section{Results}

Results were previously reported on the 953 women taking part in the study. Of these, sufficient material for the Abbott RealTime HR HPV assay was available for 858 women, for which results are presented here. The histological outcomes for the study are shown in Table 2. A total of $21.1 \%$ of the women had cervical intraepithelial neoplasia grade 3 or worse (CIN3+) and an additional $8.7 \%$ had cervical intraepithelial neoplasia grade 2 (CIN2), so that overall $29.8 \%$ had histologically confirmed high grade disease. Table 3 shows the positivity rates for different combinations of HPV 16, 18 and non-16/18 high risk types. Altogether $643 / 858$ or $74.9 \%$ of the women were positive for at least one type. Sensitivity and PPV for the Abbott test for cervical intraepithelial neoplasia grade 3 or worse $(\mathrm{CIN} 3+)$ and cervical intraepithelial neoplasia grade 2 or worse (CIN2+) are shown in Table 4. The sensitivity and specificity for the Abbott test in comparison to all the other tests are summarised in Figures 1a and $1 \mathrm{~b}$. It can be seen that all types together gave a very high sensitivity, both for cervical intraepithelial neoplasia grade 3 or worse $(\mathrm{CIN} 3+)(98.9 \%, 179 / 181)$ and cervical intraepithelial neoplasia grade 2 or worse $(\mathrm{CIN} 2+)(97.7 \%, 250 / 256)$. The positive predictive value (PPV) was higher for HPV16 than other types, being almost $60 \%$ for cervical intraepithelial neoplasia grade 2 or worse (CIN2+), whereas the other types (including type 18) had PPVs in the 30-35\% range for cervical intraepithelial neoplasia grade 2 or worse (CIN2+). HPV 18 was more predictive for cervical intraepithelial neoplasia grade 3 or worse (CIN3+) (31.5\%) than the non-16/18 HR types (21.4\%), but still less than for HPV 16 (46.5\%). PPVs for HPV 18 were substantially higher in younger women than for those aged 30y or more, but the PPVs for HPV16 and the non-16/18 HR types did not vary appreciably by age. 
Table 5 indicates the concordance between the Abbott test and the other tests both for all high risk types and types 16 and 18 separately (vs. Linear Array, the PreTect HPV-Proofer Clinical Arrays, and q-PCR). It can be seen that the concordance was highest with Linear Array, but was also quite high with Hybrid Capture II and APTIMA. Poor correlation was seen with the PreTect HPV-Proofer, p16 and Clinical-Arrays. When restricted to types 16 and 18 concordance was again highest with Linear Array, but improved substantially with the PreTect HPV-Proofer and our in-house q-PCR. Of the 27 women with discordant results for HPV 16 between the Abbott assay and the Roche Linear Assay, the 22 women were positive for Linear Assay containing 6 cervical intraepithelial neoplasia grade 2 or worse (CIN2+) cases, while all 5 cases only positive for the Abbott assay had less than cervical intraepithelial neoplasia grade 2 (CIN2). For the 13 women positive for HPV 18 only by Linear Assay, 4 had cervical intraepithelial neoplasia grade grade 2 or worse (CIN2+). No woman was positive for HPV 18 by the Abbott assay, but not the Roche Linear Array.

Figures $2 \mathrm{a}$ and $2 \mathrm{~b}$ show the viral load ROC curves characterizing the effect of cycle number cutoff setting on test performance for the detection of intraepithelial neoplasia grade 3 or worse (CIN3+) and intraepithelial neoplasia grade 2 or worse (CIN2+), respectively. Changing the cutoff of cycle number from $\leq 32$ to $\leq 30$ would leave the sensitivity unchanged (98.9\% for intraepithelial neoplasia grade 3 or worse (CIN3+), 97.7\% for intraepithelial neoplasia grade 2 or worse (CIN2+)) but would increase specificity to $35.5 \%$ instead of $31.5 \%$ for cervical intraepithelial neoplasia grade 3 or worse (CIN3+) and to $39.2 \%$ instead of $34.7 \%$ for cervical intraepithelial neoplasia grade 2 or worse (CIN2+). The PPV was raised from $27.8 \%$ to $29.1 \%$ for cervical intraepithelial neoplasia grade 3 or worse (CIN3+) and from $38.9 \%$ to $40.6 \%$ for cervical intraepithelial neoplasia grade 2 or worse (CIN2+). 
Abbott RealTime High Risk HPV

For cervical intraepithelial neoplasia grade 3 or worse $(\mathrm{CIN} 3+)$ the slope of the ROC curve changed between 24 and 25 cycles. If the cutoff was reduced to $\leq 24.5$, the sensitivity for cervical intraepithelial neoplasia grade 3 or worse (CIN3+) would decrease to $90.1 \%$ (84\% for cervical intraepithelial neoplasia grade 2 or worse (CIN2+)) while a substantial increase would be observed for both specificity (52.6\% for cervical intraepithelial neoplasia grade 3 or worse (CIN3+), 55.3\% for cervical intraepithelial neoplasia grade 2 or worse (CIN2+)) and PPV (33.7\% for intraepithelial neoplasia grade 3 or worse (CIN3+), 44.4\% for cervical intraepithelial neoplasia grade 2 or worse $(\mathrm{CIN} 2+))$. 


\section{Discussion}

The Abbott RealTime HR HPV test demonstrated a very high sensitivity for cervical intraepithelial neoplasia grade 2 or worse $(\mathrm{CIN} 2+)$ and cervical intraepithelial neoplasia grade 3 or worse (CIN3+), in the same range as the Qiagen Hybrid Capture II test, the Roche Amplicor and Linear Array tests, and slightly better than the Gen-Probe APTIMA test. The concordance with these tests was also quite high. The specificity was slightly better than Hybrid Capture II, Linear Array and Amplicor tests, but not as high as the APTIMA test. This suggests the difference between these tests is largely based on the cutoff threshold. The positive predictive value of HPV 16 and to a less extent HPV 18 was greater than for the other high risk types, indicating that this information could be useful for determining who needs immediate referral and who can be safely managed by repeat testing.

These results suggest that the Abbott RealTime HR HPV test is a promising candidate for use in primary screening, and further studies are needed to evaluate its performance directly in this context. 
Abbott RealTime High Risk HPV

\section{Acknowledgements}

We would like to thank the staff in the departments of Cytopathology and Colposcopy at the Hammersmith Hospital and St. Mary’s Hospital, London, for their help with this study.

\section{Conflicts of interest}

The following companies provided test kits and a financial contribution to the first author's institution to help conduct this study:

Abbott, Qiagen, Gen-Probe Incorporated, Genomica S.A.U, mtm laboratories, NorChip and Roche Diagnostics 


\section{References}

Almonte M. Ferreccio C, Winkler J, Cuzick J, Tsu V. Robles S, Takahashi R, Sasieni P. 2007. Cervical screening by visual inspection, HPV testing, liquid-based and conventional cytology in Amazonian Peru. International Journal of Cancer 121:796-802

Bulkmans NW, Berkhof J, Rozendaal L, van Kemenade FJ, Boeke AJ, Bulk S, Voorhorst FJ, Verheijen RH, van Groningen K, Boon ME, Ruitinga W, van Ballegooijen M, Snijders PJ, Meijer CJ. 2007. Human papillomavirus DNA testing for the detection of cervical intraepithelial neoplasia grade 3 and cancer: 5-year follow-up of a randomised controlled implementation trial. Lancet 370(9601):1764-72.

Bulkmans NW, Rozendaal L, Voorhorst FJ, Snijders PJ, Meijer CJ. 2005. Long-term protective effect of high risk human papillomavirus testing in population-based cervical screening. British Journal of Cancer 92:1800-2.

Cuzick J, Szarewski A, Cubie H, Hulman G, Kitchener H, Luesley D, McGoogan E, Menon U, Terry G, Edwards R, Brooks C, Desai M, Gie C, Ho L, Jacobs I, Pickles C, Sasieni P. 2003. Management of women who test positive for high risk types of human papillomavirus: the HART study. Lancet 362:1871-6.

Cuzick J, Clavel C, Petry KU, Meijer CJ, Hoyer H, Ratnam S, Szarewski A, Birembaut P, Kulasingam S, Sasieni P, Iftner T. 2006. Overview of the European and North American studies on HPV testing in primary cervical screening. International Journal of Cancer 119:1095-101.

Cuzick J, Szarewski A, Mesher D, Cadman L, Austin J, Perryman K, Ho L, Terry G, Sasieni P, Dina R, Soutter WP. 2008. Long-term follow-up of cervical abnormalities among women screened by HPV testing and cytology - Results from the Hammersmith study. International Journal of Cancer 122(10):2294-300.

Dillner J, Rebolj M, Birembaut P, Petry KU, Szarewski A, Munk C, de Sanjose S, Naucler P, Lloveras B, Kjaer S, Cuzick J, van Ballegooijen M, Clavel C, Iftner T; Joint European Cohort Study. 2008. Long term predictive values of cytology and human papillomavirus testing in cervical cancer screening: joint European cohort study. British Medical Journal 337:a1754.

Khan MJ, Castle PE, Lorincz AT, Wacholder S, Sherman M, Scott DR, Rush BB, Glass AG, Schiffman M. 2005. The elevated 10-year risk of cervical precancer and cancer in women with human papillomavirus (HPV) type 16 or 18 and the possible utility of type-specific HPV testing in clinical practice. Journal of the National Cancer Institute 97:10729.

Kotaniemi-Talonen L, Anttila A, Malila N, Tarkkanen J, Laurila P, Hakama M, Nieminen P. 2008. Screening with a primary human papillomavirus test does not increase detection of cervical cancer and intraepithelial neoplasia 3. European Journal of Cancer 44(4):565-71.

Mayrand MH, Duarte-Franco E, Rodrigues I, Walter SD, Hanley J, Ferenczy A, Ratnam S, Coutlée F, Franco EL. 2007. Canadian Cervical Cancer Screening Trial Study Group. Human papillomavirus DNA versus Papanicolaou screening tests for cervical cancer. New England Journal of Medicine 357(16):1579-88. 
Naucler P, Ryd W, Törnberg S, Strand A, Wadell G, Elfgren K, Rådberg T, Strander B, Forslund O, Hansson BG, Rylander E, Dillner J. 2007. Human papillomavirus and Papanicolaou tests to screen for cervical cancer. New England Journal of Medicine 357(16):1589-97.

Ronco G, Giorgi-Rossi P, Carozzi F, Confortini M, Dalla Palma P, Del Mistro A, Gillio-Tos A, Minucci D, Naldoni C, Rizzolo R, Schincaglia P, Volante R, Zappa M, Zorzi M, Cuzick J, Segnan N. 2008. New Technologies for Cervical Cancer Screening Working Group. Results at recruitment from a randomized controlled trial comparing human papillomavirus testing alone with conventional cytology as the primary cervical cancer screening test. Journal of the National Cancer Institute 100(7):492-501.

Szarewski A, Ambroisine L, Cadman L, Austin J, Ho L, Terry G, Liddle S, Dina R, McCarthy J, Buckley H, Bergeron C, Soutter P, Lyons D, Cuzick J. 2008. Comparison of Predictors for High-Grade Cervical Intraepithelial Neoplasia in Women with Abnormal Smears. Cancer Epidemiology Biomarkers \& Prevention 17(11):3033-42.

Walboomers JM, Jacobs MV, Manos MM, Bosch FX, Kummer JA, Shah KV, Snijders PJ, Peto J, Meijer CJ, Muñoz N. 1999. Human papillomavirus is a necessary cause of invasive cervical cancer worldwide. The Journal of Pathology 189:12-9. 
3

4

5

7

9

Table 1. Characteristics of the different HPV tests employed in this study.

\begin{tabular}{|c|c|c|c|}
\hline $\begin{array}{c}\text { Test } \\
\text { Manufacturer }\end{array}$ & Target & Types Detected & Methodology \\
\hline $\begin{array}{c}\text { Hybrid Capture II } \\
\text { Qiagen }\end{array}$ & DNA & $\begin{array}{c}16,18,31,33,35,39,45 \\
51,52,56,58,59,68\end{array}$ & $\begin{array}{c}\text { Signal amplification by } \\
\text { hybridization to a cocktail } \\
\text { of RNA probes } \\
\text { chemiluminescent } \\
\text { detection }\end{array}$ \\
\hline $\begin{array}{c}\text { Amplicor } \\
\text { Roche Diagnostics }\end{array}$ & DNA & As above & $\begin{array}{l}\text { Consensus PCR } \\
40 \text { cycles }\end{array}$ \\
\hline $\begin{array}{c}\text { Linear Array } \\
\text { Roche Diagnostics }\end{array}$ & Type-specific DNA & $\begin{array}{l}37 \text { types including those } \\
\text { above }\end{array}$ & $\begin{array}{c}\text { PcR with PGMY primers } \\
40 \text { cycles } \\
\text { Type-specific } \\
\text { oligonucleotide probes } \\
\text { colorimetric detection }\end{array}$ \\
\hline $\begin{array}{l}\text { Clinical Arrays } \\
\text { Genomica }\end{array}$ & Type-specific DNA & $\begin{array}{l}35 \text { types including those } \\
\text { above }\end{array}$ & $\begin{array}{l}\text { MY09/11 Primers } \\
\text { PCR with } 45 \text { cycles } \\
\text { Low density microarray } \\
\text { colorimetric detection }\end{array}$ \\
\hline $\begin{array}{l}\text { PreTect HPV-Proofer } \\
\text { Norchip }\end{array}$ & $\begin{array}{c}\text { Type-specific E6/E7 } \\
\text { mTNA }\end{array}$ & $16,18,31,33,35$ & $\begin{array}{l}\text { Multiplex NASBA } \\
\text { isothermal amplification } \\
\text { real time detection }\end{array}$ \\
\hline $\begin{array}{l}\text { APTIMA } \\
\text { Gen-Probe }\end{array}$ & Consensus E6/E7 mRNA & $\begin{array}{l}13 \text { types listed above } \\
\text { plus } 66\end{array}$ & $\begin{array}{c}\text { Target Capture (Magnetic } \\
\text { Particles } \\
\text { Transcription mediated } \\
\text { Amplification } \\
\text { (Isothermal) } \\
\text { Hybridization protection }\end{array}$ \\
\hline $\begin{array}{c}\text { RealTime HR HPV } \\
\text { Abbott }\end{array}$ & $\begin{array}{l}\text { Consensus and Limited } \\
\text { type-specific DNA }\end{array}$ & $\begin{array}{l}14 \text { types above plus type- } \\
\text { specific for HPV } 16+18\end{array}$ & $\begin{array}{l}\text { RealTime PcR of LI } \\
\text { region } \\
\text { Threshold cycle } 32 \text { multi- } \\
\text { colour detection }\end{array}$ \\
\hline $\begin{array}{c}\mathrm{p} 16^{\mathrm{INK4a}} \\
\mathrm{mtm} \text { Laboratories }\end{array}$ & p16 protein & & $\begin{array}{l}\text { Immunohistochemistry } \\
\text { with mouse monochloral } \\
\text { antibody to } 16^{\mathrm{INK} 4 \mathrm{a}} \text { with } \\
\text { second anti-mouse } \\
\text { antibody and DAB } \\
\text { chromogen detection }\end{array}$ \\
\hline
\end{tabular}


Abbott RealTime High Risk HPV

Table 2. Distribution of worst reviewed histological outcomes in the study.

\begin{tabular}{lcc}
\hline Worst histology (reviewed) & Freq. & $\%$ \\
\hline Normal colposcopy / Negative biopsy & 386 & 45.0 \\
Unsatisfactory & 9 & 1.0 \\
HPV only / Borderline & 127 & 14.8 \\
CIN 1 / CIN ungradable / CGIN low grade & 80 & 9.3 \\
CIN 2 & 75 & 8.7 \\
CIN 3 & 165 & 19.2 \\
CGIN high grade & 4 & 0.5 \\
Invasive carcinoma & 12 & 1.4 \\
\hline Total & 858 & 100.0 \\
\hline
\end{tabular}

CIN - cervical intraepithelial neoplasia 
Table 3. Prevalence of the different HPV types using the Abbott RealTime HR HPV test.

\begin{tabular}{lcc}
\hline Type & No. positive & \%positive \\
\hline HPV16 alone & 126 & 14.7 \\
HPV16 any & 243 & 28.3 \\
HPV 18 alone & 25 & 2.9 \\
HPV 18 any & 73 & 8.5 \\
Other HR alone & 344 & 40.1 \\
Other HR any & 486 & 56.6 \\
HPV16 \& 18 (w/o others) & 6 & 0.7 \\
HPV16 \& other HR (w/o 18) & 100 & 11.6 \\
HPV18 \& other HR (w/0 16) & 31 & 3.6 \\
All 3 groups & 11 & 1.3 \\
Any high risk type & 643 & 74.9 \\
\hline
\end{tabular}


Abbott RealTime High Risk HPV

Table 4. PPV and sensitivity of Abbott RealTime HR HPV test and PPV of type-specific detection for a) cervical intraepithelial neoplasia grade 3 or worse (CIN3+) and b) cervical intraepithelial neoplasia grade 2 or worse $(\mathrm{CIN} 2+)$, overall and according to age $(<30, \geq 30)$. Numbers for sensitivity add up to more than $100 \%$ due to multiple types.

a) $\operatorname{CIN} 3+(\mathrm{n}=181)$

\begin{tabular}{llccc}
\hline & Age & $\begin{array}{c}\text { No. with disease \& } \\
\text { positive / } \\
\text { No. positive for type }\end{array}$ & PPV & Sensitivity \\
\hline $\begin{array}{l}\text { Abbott RealTime } \\
\text { HR HPV }\end{array}$ & All & $179 / 643$ & 27.8 & 98.9 \\
& $<30$ & $93 / 356$ & 26.1 & 97.9 \\
HPV16 & $\geq 30$ & $86 / 287$ & 30.0 & 100.0 \\
& All & $113 / 243$ & 46.5 & - \\
HPV18 & $<30$ & $64 / 142$ & 45.1 & - \\
& $\geq 30$ & $49 / 101$ & 48.5 & - \\
All other HR types & All & $23 / 73$ & 31.5 & - \\
& $<30$ & $16 / 40$ & 40.0 & - \\
& All & $7 / 33$ & 21.2 & - \\
& $<30$ & $104 / 486$ & 21.4 & - \\
\hline
\end{tabular}

b) $\operatorname{CIN2+}(\mathrm{n}=256)$

\begin{tabular}{llclc}
\hline & Age & $\begin{array}{c}\text { No. with disease\& } \\
\text { positive } / \\
\text { No. positive for type }\end{array}$ & PPV & Sensitivity \\
\hline Abbott RealTime & All & $250 / 643$ & 38.9 & \\
HR HPV & $<30$ & $133 / 356$ & 37.4 & 97.7 \\
& $\geq 30$ & $117 / 287$ & 40.8 & 97.1 \\
HPV16 & All & $140 / 243$ & 57.6 & - \\
& $<30$ & $77 / 142$ & 54.2 & - \\
HPV18 & $\geq 30$ & $63 / 101$ & 62.4 & - \\
& All & $25 / 73$ & 34.2 & - \\
All other HR types & $\mathbf{4}$ & $16 / 40$ & 40.0 & - \\
& $<30$ & $9 / 33$ & 27.3 & - \\
& All & $159 / 486$ & 32.7 & - \\
& $<30$ & $89 / 282$ & 31.6 & - \\
\hline
\end{tabular}

* HPV 31, 33, 35, 39, 45, 51, 52, 56, 58, 59, 66, and 68. 
Table 5. Summary of discordant results between Abbott RealTime HR HPV test and the other tests for all individuals. The table shows the discordant results between two tests $(\mathrm{A}, \mathrm{B})$ : A (positive for the test in the first column, negative for Abbott RealTime HR HPV test), B (negative for the test in the first column, positive for Abbott RealTime HR HPV test) for all HR HPV types (second column), HPV16 (third column) and HPV18 (fourth column), and the value of Cohen's kappa statistic. For all comparisons, $\mathrm{p}<0.0001$.

\begin{tabular}{lccc}
\hline \multicolumn{4}{c}{ Abbott RealTime HR HPV } \\
HR HPV types & HPV16 & HPV18 \\
\hline \multirow{2}{*}{ Hybrid Capture II } & $(62,20)^{*}$ & & \\
& $\mathrm{~K}=0.73$ & & \\
Amplicor & $(98,11)$ & & \\
& $\mathrm{K}=0.61$ & & \\
PreTect HPV-Proofer & $(4,284)$ & $(7,36)$ & $(0,21)$ \\
& $\mathrm{K}=0.36$ & $\mathrm{~K}=0.87$ & $\mathrm{~K}=0.81$ \\
APTIMA & $(29,77)$ & & \\
& $\mathrm{K}=0.69$ & & \\
CINtec p16 & & & \\
& $(25,160)$ & & \\
Linear Array & $\mathrm{K}=0.27$ & & \\
& $(36,31)$ & $(22,5)$ & $(13,0)$ \\
Clinical-Arrays & $\mathrm{K}=0.78$ & $\mathrm{~K}=0.92$ & $\mathrm{~K}=0.91$ \\
& $(72,118)$ & $(126,25)$ & $(79,18)$ \\
q-PCR & $\mathrm{K}=0.30$ & $\mathrm{~K}=0.52$ & $\mathrm{~K}=0.38$ \\
& & & \\
& $(46,139)$ & $(26,17)$ & $(45,4)$ \\
$\mathrm{K}=0.49$ & $\mathrm{~K}=0.87$ & $\mathrm{~K}=0.80$ \\
\hline
\end{tabular}

* eg (62 individuals positive for Hybrid Capture II and negative for Abbott RealTime HR HPV, 20 individuals negative for Hybrid Capture II and positive for Abbott RealTime HR HPV). 
Abbott RealTime High Risk HPV

Figure 1a, 1b. Summary of comparative sensitivity and specificity for cervical intraepithelial neoplasia grade 3 or worse (CIN3+) (a) and cervical intraepithelial neoplasia grade 2 or worse (CIN2+) (b) for all tests evaluated in the study

a) $\mathrm{CIN} 3+$

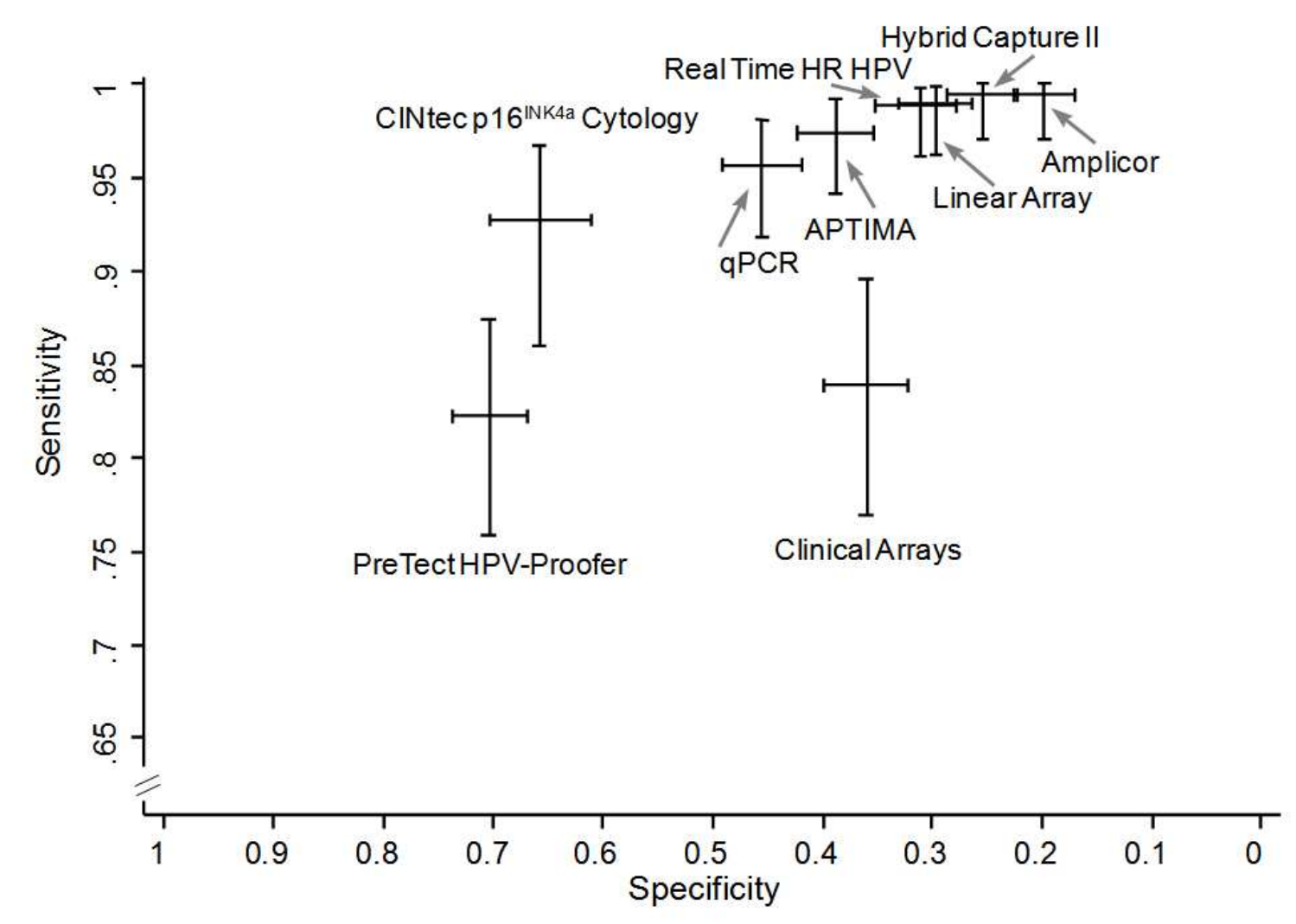


b) $\mathrm{CIN} 2+$

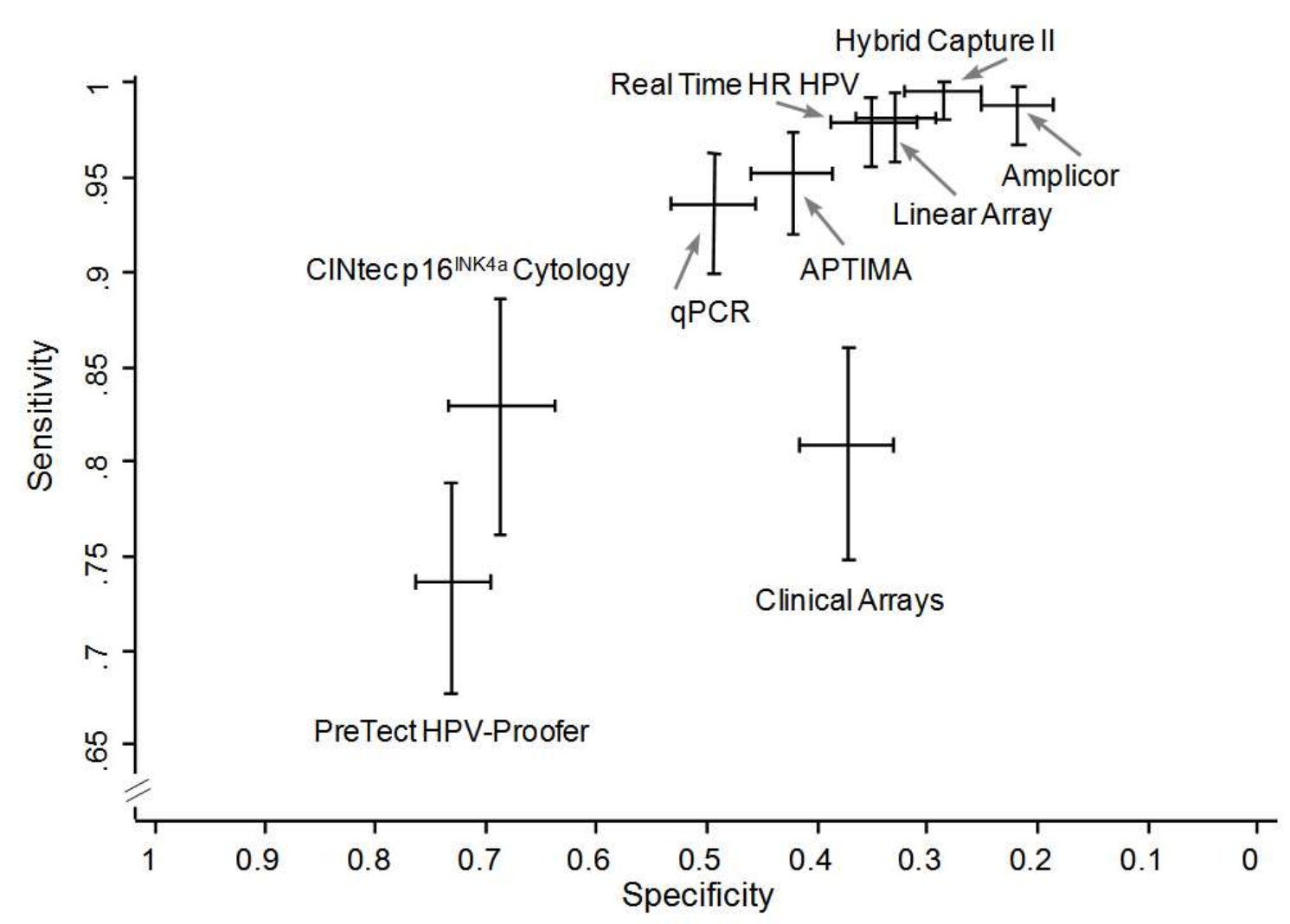


Abbott RealTime High Risk HPV

Figure 2a, 2b. Viral load Receiver Operating Characteristic (ROC) curves of different cycle number assay cutoff settings for detection of cervical intraepithelial neoplasia grade 3 or worse $(\mathrm{CIN} 3+)$ (a) and cervical intraepithelial neoplasia grade 2 or worse (CIN2+) (b)

a) $\mathrm{CIN} 3+$

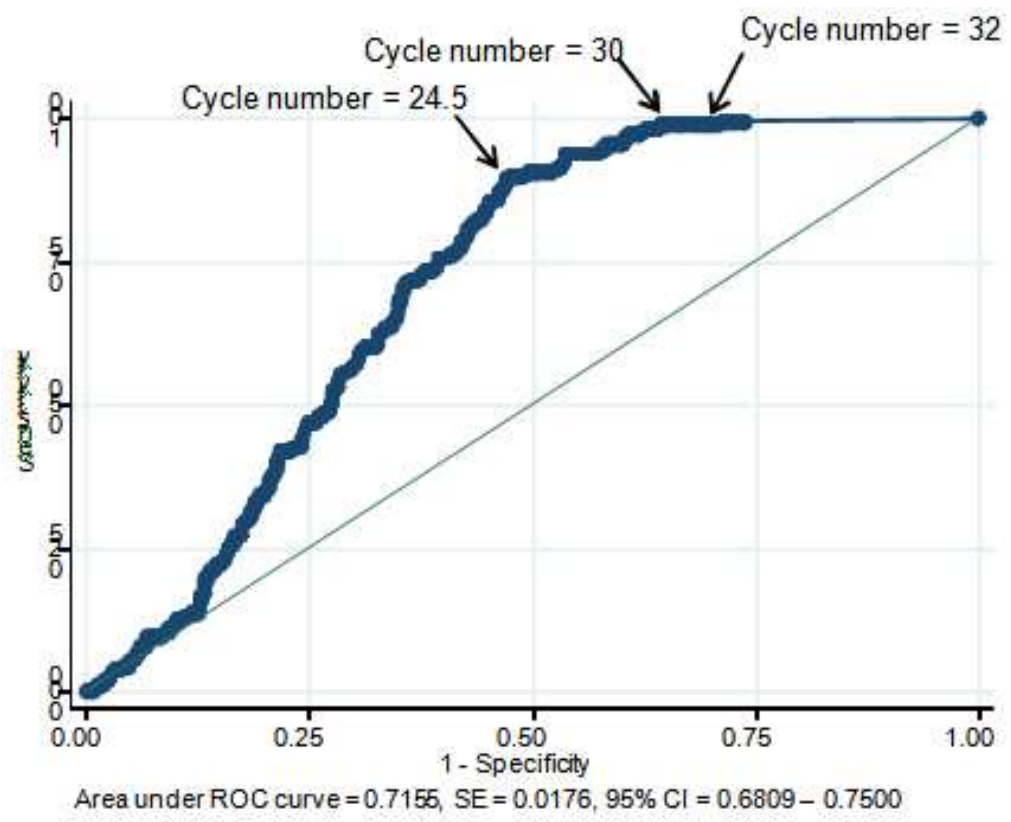


b) CIN2+

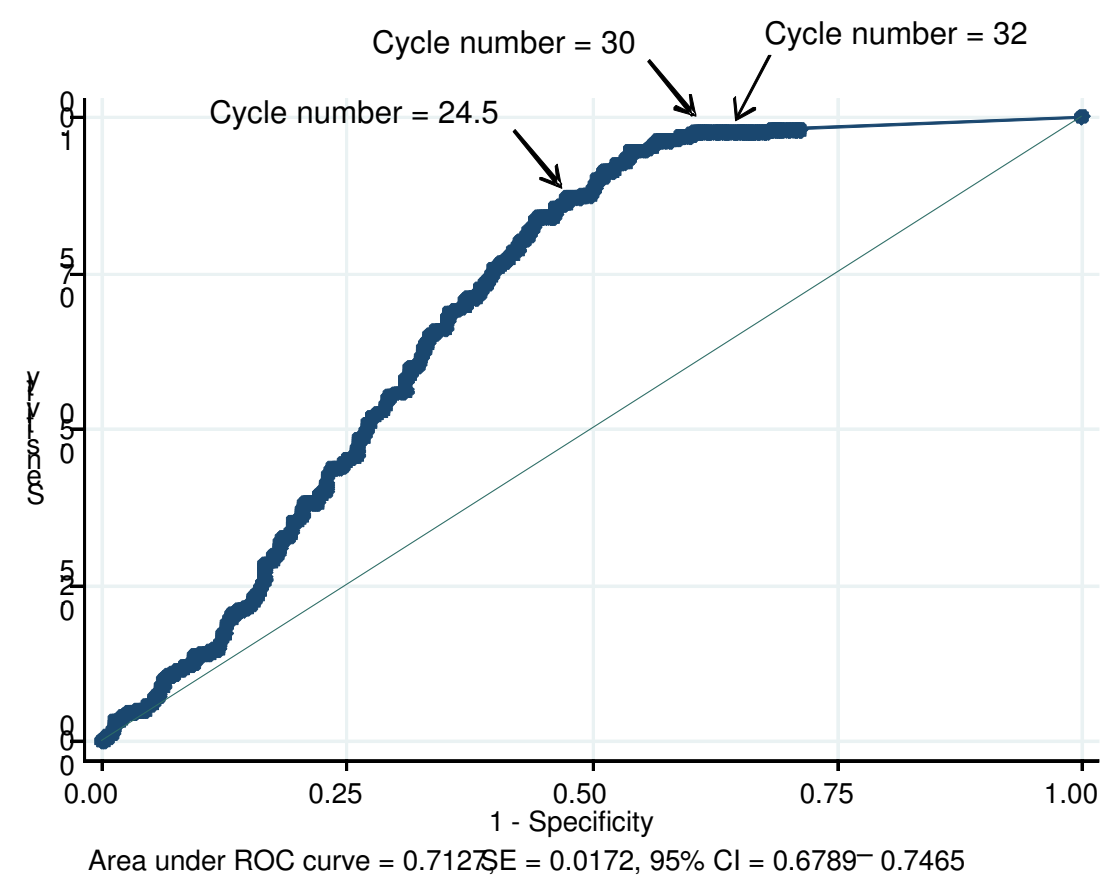

